\title{
COST EVALUATION OF THE ANTIHELICOBACTER THERAPY OF GASTRODUODENAL ULCERS
}

\author{
O.O.Gerasymova, A.A.Krasiuk
}

\author{
National University of Pharmacy
}

Key words: peptic ulcer; duodenal ulcer; antihelicobacter therapy; cost of treatment

\begin{abstract}
The results of cost evaluation of the antihelicobacter therapy regimen of gastroduodenal ulcers recommended by the Ukrainian unified clinical protocol of medical care to adult patients with this disease (order of the Ministry of Health of Ukraine No. 613 dated 03.09.2014), which is based on the principles of evidence-based medicine, are presented. It has been found that most medicines used in the antihelicobacter therapy regimen were presented at the pharmaceutical market of Ukraine in 2014 in sufficient quantities with a wide range of prices per a drug unit. The cost ranges of the antihelicobacter therapy are: the first-line therapy - from 87.50 to $3400.88 \mathrm{UAH}$ (the triple therapy - from 181.44 to $3400.88 \mathrm{UAH}$; the sequential therapy - from 87.50 to 1837.65 UAH); the second-line therapy (quadrotherapy) - from 202.60 to 2059.19 UAH; the therapy of salvation - from 157.08 to $3298.93 \mathrm{UAH}$. The total costs of therapy for the patient with therapy of salvation are from 628.62 to 10596.65 UAH. The variants of the antihelicobacter therapy regimen have been proposed. They are formed from the medicines presented at the Ukrainian pharmaceutical market and the State Formulary of Ukraine, and have the lowest costs for the course of the antihelicobacter therapy of the disease. Their use is economically feasible for the Ukrainian low solvent patients with peptic and duodenal ulcers.
\end{abstract}

Deptic ulcer (PU) and duodenal ulcer (DU) are one of the expensive of gastroenterological diseases. The average annual cost of treating a patient with $\mathrm{PU}$ is from \$ 959.60 to 2553.10 in South Korea, and \$ 23819 in the USA [13]. The total cost of inpatient treatment (direct and indirect costs) of a patient with DU associated with Helicobacter pylori (H. pylori) is on average $\$ 708.60$ in Russia [3]. In the USA more than $\$ 750$ million are spent per year for the treatment of PU complicated with bleeding [8].

According to the international and national guidelines for treatment of gastroenterological patients the main treatment strategy of PU and DU associated with H. pylori is to conduct the antihelicobacter therapy (AHT) [7, 9-14]. The successful eradication of $H$. pylori contributes to activation of the regeneration process and scarring ulcers, reduces the probability of developing recurrence and complications. The basic requirements for AHT are good tolerability (the frequency of side effects is less than 5\%), the effectiveness for the course of treatment is no longer than 7-14 days, the level of $H$. pylori eradication is not less than $80 \%$ and economic feasibility [9]. Antisecretory medicines (proton pump inhibitors (PPIs)), antibacterial medicines exhibiting the activity against H. pylori (most often amoxicillin, clarithromycin, tetracycline, metronidazole), and bismuth medicines having the cytoprotective and antibacterial properties are used for AHT $[5,9,10,12]$. The cost of AHT constitutes a significant proportion of the costs for treating PU and DU. Each year more than 500 million EUR are spent only for the purchase of antisecretory medicines in Germany [4].

The aim of this work was to evaluate costs for AHT of PU and DU in adult patients in Ukraine.

The tasks of the study were as follows:

1) analysis of the assortment of medicines used for AHT of PU and DU at the pharmaceutical market of Ukraine;

2) determination of the cost range for the regimens of the first and second line of AHT, therapy of salvation per one adult patient in Ukraine;

3 ) formation of the least expensive AHT regimens from medicines presented at the pharmaceutical market of Ukraine.

\section{Materials and Methods}

The objects of our research were regimens of AHT recommended for treating PU and DU by unified clinical protocols of the primary, secondary (specialized) medical care "Peptic ulcer of the stomach and duodenum in adults" (order of the Ministry of Health of Ukraine No. 613 dated 03.09.2014) [7] created in accordance with the principles of evidence-based medicine:

I. The first-line therapy:

1) The triple therapy: PPI in a standard dose twice a day + amoxicillin, $1000 \mathrm{mg}$, twice a day + clarithromycin, $500 \mathrm{mg}$, twice a day for 10-14 days.

2) The triple therapy with allergy to penicillin: PPI in a standard dose twice a day + clarithromycin, $500 \mathrm{mg}$, twice a day + metronidazole, $500 \mathrm{mg}$, twice a day for 7-14 days. 


\section{The assortment of medicines used in the antihelicobacter therapy regimens of peptic and duodenal ulcers at the pharmaceutical market of Ukraine}

\begin{tabular}{|l|c|c|c|c|}
\hline $\begin{array}{c}\text { International } \\
\text { non-proprietary name }\end{array}$ & $\begin{array}{c}\text { The number of TN in } \\
\text { various dosage forms }\end{array}$ & $\begin{array}{c}\text { The ratio of foreign / } \\
\text { domestic TN }\end{array}$ & $\begin{array}{c}\text { Price per a drug unit, } \\
\text { UAH }\end{array}$ & $\begin{array}{c}\text { The number of TN in } \\
\text { the SFU }\end{array}$ \\
\hline \multicolumn{5}{|c|}{ Proton pump inhibitors } \\
\hline Omeprazole & 26 & $16 / 10$ & $5.45-178.79$ & 11 \\
\hline Lansoprazole & 8 & $5 / 3$ & $32.99-92.53$ & 6 \\
\hline Pantoprazole & 30 & $25 / 5$ & $25.61-269.04$ & 19 \\
\hline Rabeprazole & 15 & $11 / 4$ & $17.09-953.64$ & 10 \\
\hline Ezomeprazole & 12 & $12 / 0$ & $63.88-1284.83$ & 11 \\
\hline \multicolumn{5}{|c|}{ Antibacterial medicines } \\
\hline Amoxicillin & 22 & $14 / 8$ & $17.25-153.11$ & 16 \\
\hline Clarithromycin & 39 & $29 / 10$ & $37.93-426.88$ & 28 \\
\hline Levofloxacin & 50 & $27 / 23$ & $59.89-1160.24$ & 24 \\
\hline Metronidazole & 21 & $9 / 12$ & $5.90-66.94$ & 2 \\
\hline Tetracycline & 4 & $2 / 2$ & $4.05-8.66$ & 2 \\
\hline Tinidazole & 2 & $2 / 0$ & $15.08-52.42$ & \\
\hline \multicolumn{5}{|l|}{ Bismuth medicines } \\
\hline Bismuth subcitrate & 6 & $2 / 4$ & $33.54-239.75$ & 6 \\
\hline
\end{tabular}

3) The sequential therapy: PPI in a standard dose twice a day + amoxicillin, $1000 \mathrm{mg}$, twice a day for 5 days with subsequent transition to PPI + clarithromycin, $500 \mathrm{mg}$, twice a day + metronidazole (or tinidazole), $500 \mathrm{mg}$, twice a day for 5 days.

II. The second-line therapy (quadrotherapy): PPI in a standard dose twice a day + bismuth subcitrate, $120 \mathrm{mg}$, 4 times a day + metronidazole, $500 \mathrm{mg}$, 3 times a day + tetracycline, $500 \mathrm{mg}$, 4 times a day for 10-14 days. It is prescribed when the triple therapy or sequential therapy is noneffective, or there is intolerance or resistance to clarithromycin.

III. The therapy of salvation: PPI in a standard dose twice a day + amoxicillin, $1000 \mathrm{mg}$, twice a day + levofloxacin, $500 \mathrm{mg}$, once a day or rifabutin, $300 \mathrm{mg}$, once a day for 10-14 days. It is prescribed when eradication of $H$. pylori is absent after the second course of treatment.

The standard daily doses of PPIs for the treatment of Helicobacter dependent diseases are: omeprazole $-40 \mathrm{mg}$, pantoprazole -
$80 \mathrm{mg}$, rabeprazole - $40 \mathrm{mg}$, lansoprazole - $60 \mathrm{mg}$, ezomeprazole $-40 \mathrm{mg}$ [1].

The assortment of trade names (TN) of medicines under study in Ukraine and the average retail price per a drug unit in the pharmacy network in 2014 were determined according to the market research system of medicines "Pharmstandard" of "Morion" company (November 2014) [6]. The presence of TN for medicines was assessed in the current State Formulary of Ukraine (SFU) (the 6-th ed.) [2]. This document regulates the rational choice of drug TN for pharmacotherapy of diseases. Costs for the use of medicines in the composition of AHT regimens for PU and DU per one patient were calculated per the course of treatment - 14 days (for sequential therapy - 10 days). Only costs on medicines were taken into account when calculating the cost.

\section{Results and Discussion}

The analysis of the assortment of PPIs, bismuth and antibacterial medicines in tablets used in the AHT regimens at the dome- stic pharmaceutical market has shown that most medicines of proton pump inhibitors, amoxicillin, clarithromycin and metronidazole medicines are presented in Ukraine by many TN (Table). These drugs are used in the AHT regimens most often. They are offered by several manufacturers. Therefore, their price range is sufficiently wide. It may significantly influence on the cost of treating a patient with $\mathrm{PU}$ and DU. Moreover, the antibacterial medicine levofloxacin prescribed only in the "therapy of salvation» is presented in Ukraine by the largest number of TN among the medicines studied. Rifabutin is its alternative in accordance with the clinical protocol [7]. Trade names of this medicine is absent at the Ukrainian pharmaceutical market. Most of the medicines studied are presented in various dosage forms (with different doses and the different number of tablets in a pack). This makes possible to reduce the cost of treatment by choosing the dosage form with minimal costs. It should be noted that not all TN of medicines for 
AHT were present in the SFU (the 6-th ed.) (Table).

For all medicines included in the AHT regimens and presented at the Ukrainian pharmaceutical market the cost of the treatment course per an adult patient with PU and DU was calculated. Medicines of PPIs (omeprazole, pantoprazole, rabeprazole, lansoprazole, ezomeprazole), antibacterial medicines (amoxicillin, clarithromycin, tetracycline, metronidazole, tinidazole, levofloxacin) and bismuth subcitrate with minimum and maximum costs per a course of treatment were determined by the results of the calculations. The variants of the regimens under study were formed according to these calculations, and the cost range of the AHT regimen of $\mathrm{PU}$ and DU of the first and secondline therapy, therapy of salvation for one patient was identified.

The costs ranges of the antihelicobacter therapy are: the first-line therapy - from 87.50 to 3400.88 UAH (the triple therapy from 181.44 to $3400.88 \mathrm{UAH}$; the sequential therapy - from 87.50 to $1837.65 \mathrm{UAH}$ ); the second-line therapy (quadrotherapy) - from 202.60 to $2059.19 \mathrm{UAH}$; the therapy of salvation - from 157.08 to $3298.93 \mathrm{UAH}$. The total costs for the patient in the therapy of salvation are from 628.62 to 10596.65 UAH.

The difficult socio-economic situation in Ukraine determines the choice of medicines by a doctor for regimens of AHT to patients with a low solvency. According to the results of calculations the variants of regimens studied were formed from the least costly medicines, and their cost per a course of treatment was calculated. Only TN of medicines from the SFU (the 6-th ed.) were included in these regimens:

I. The first-line therapy:

1) The triple therapy (14 days): Omeprazole "Pharmac" caps., $0.02 \mathrm{~g}$, No.30 (14.84 UAH) + KleronMaxPharma "MaxPharma Limited" tabl., 250 mg, No.14 (151.76 UAH) + Gramox-A "Sperco Ukraine" caps., $500 \mathrm{mg}$, No.20 (48.72 UAH). The cost of the regimen is $215.32 \mathrm{UAH}$.

2) The triple therapy with allergy to penicillin (14 days): Omeprazole "Pharmac" caps., $0.02 \mathrm{~g}$, No.30 (14.84 UAH) + KleronMaxPharma "MaxPharma Limited" tabl., 250 mg, No.14 (151.76 UAH) + Metrogil $^{\circledR}$ "J.B. Chemicals \& Pharmaceuticals" tabl., $200 \mathrm{mg}$, No.100 (14.84 UAH). The cost of the regimen is $181.44 \mathrm{UAH}$.

3) The sequential therapy (10 days): Omeprazole "Pharmac" caps., 0.02 g, No.30 (10.60 UAH) + Gramox-A "Sperco Ukraine" caps., $500 \mathrm{mg}$, No.20 (17.40 UAH) + Kleron-MaxPharma "MaxPharma Limited" tabl., $250 \mathrm{mg}$, No.14 $(54.20 \mathrm{UAH})+$ Metrogil $^{\circledR}$ "J.B. Chemicals \& Pharmaceuticals" tabl., $200 \mathrm{mg}$, No.100 (5.30 UAH). The cost of the regimen is $87.50 \mathrm{UAH}$.

II. The second-line therapy (quadrotherapy) (14 days): Omeprazole "Pharmac" caps., $0.02 \mathrm{~g}$, No.30 (14.84 UAH) + Vis-nol ${ }^{\circledR}$ "Pharmac" caps., 120 mg, No.100 (52.50 UAH) + Tetracycline hydrochloride "BCPP" tabl., $100 \mathrm{mg}$, No.20 (113.26 UAH) + Metrogil $^{\circledR}$ "J.B. Chemicals \& Pharmaceuticals" tabl., $200 \mathrm{mg}$, No.100 (21.98 UAH). The cost of the regimen is $202.58 \mathrm{UAH}$.

III. The therapy of salvation (14 days): Omeprazole "Pharmac" caps., 0.02 g, No.30 (14.84 UAH) + Gramox-A "Sperco Ukraine" caps., 500 mg, No.20 (48.72 UAH) + Leflocin $^{\circledR}$ "Yuriya Farm" tabl.,
$500 \mathrm{mg}$, No.10 (93.52 UAH). The cost of the regimen is $157.08 \mathrm{UAH}$. CONCLUSIONS

1. Most medicines used in the AHT regimens are presented at the pharmaceutical market of Ukraine in sufficient quantities with a wide range of prices per a drug unit. This gives opportunities for their rational choice for the treatment of patients with PU and DU taking into account the individual characteristics of the patient and his/her solvency.

2. The cost of the AHT regimens of PU and DU per one adult patient can be quite high in Ukraine and depends on representatives of PPIs, antibacterial medicines and bismuth medicines that are included in them. The lowest cost of the AHT regimens of PU and DU of the first and secondline therapy, the therapy of salvation has been determined using the following TN of these medicines (present in the current SFU (the 6-th ed.)): among PPIs medicines - Omeprazole "Pharmac" caps., 0.02 g, No.30; among clarithromycin medicines - KleronMaxPharma "MaxPharma Limited" tabl., 250 mg, No.14; among amoxicillin medicines - Gramox-A "Sperco Ukraine" caps., 500 mg, No.20; among metronidazole medicines Metrogil ${ }^{\circledR}$ "J.B. Chemicals \& Pharmaceuticals" tabl., 200 mg, No.100; among tetracycline medicines Tetracycline hydrochloride "BCPP" tabl., 100 mg, No.20; among levofloxacin medicines - Leflocin ${ }^{\circledR}$ "Yuriya Farm" tabl., 500 mg, No.10; among bismuth medicines - Visnol $^{\circledR}$ "Pharmac" caps., 120 mg, No.100. Using the regimens formed from these TN of medicines is economically feasible the Ukrainian low solvent patients with PU and DU. 


\title{
REFERENCES
}

1. Адаптована клінічна настанова, заснована на доказах «Пептична виразка шлунка та дванадиятипалої кишки». - Режим доступу: http://www.dec.gov.ua/mtd/reestr.html.

2. Державний формуляр лікарських засобів України (шостий випуск, 2014 р.). - Режим доступу: http://www.dec.gov.ua/index.php/ua/site-terms.

3. Лазебник Л.Б., Гусейнзаде М.Г., Ефремов Л.И. // Качественная клиническая практика. - 2008. №2. - C. 62-70.

4. Лазебник Л.Б., Машарова А.А., Гусейнзаде М.Г. // Эксперим. и клиническая гастроэнтерол. 2006. - №4. - C. 1-6.

5. Маев И.В., Самсонов А.А., Голубев Н.Н. и др. // Фарматека. - 2011. - №2. - С. 10-17.

6. Система дослідження ринку «Фармстандарт» компанії «Моріон». - Режим доступу: http:// pharmbase.com.ua/poisk/.

7. Уніфікований клінічний протокол первинної, вторинної (спеціалізованої) медичної допомоги «Пептична виразка шлунка та дванадиятипалої кишки у дорослих». - Режим доступу: httр:// www.dec.gov.ua/mtd/reestr.html.

8. Фомин П.Д., Никишаев В.И. // Здоров'я України. - 2010. - №2. - С. 8-11.

9. Харченко Н.В., Опанасюк Н.Д., Токарь Д.В. // Сучасна гастроентерол. - 2009. - №5 (49). - С. 89-93.

10. Jyh-Chin Yang, Chien-Wei Lu, Chun-Jung Lin // World J. Gastroenterol. - 2014. - Vol. 20, Iss. 18. P. 5283-5293.

11. Malfertheiner P., Megraud F., O'Morain C.A. et al. // Gut . - 2012. - №61. - P. 646-664.

12. Sebahat Basyigit, Ayse Kefeli, Ferdane Pirincci Sapmaz et al. // Bosn. J. Basic Med. Sci. - 2015. - Vol. 15, №4. - P. 50-54.

13. Wei-Ping Bi, Hui-Bin Man, Mao-Qiang Man // World J. of Gastroenterol. - 2014. - Vol. 20, Iss. 45. P. 17020-17028.

14. Zagari R.M., Romano M., Ojetti V. et al. // Digestive and Liver Disease. - 2015. - №47. - P. 903-912.

ОЦІНКА ВИТРАТ НА АНТИХЕЛІКОБАКТЕРНУ ТЕРАПІЮ ВИРАЗКОВОЇ ХВОРОБИ ШЛУНКА ТА ДВАНАДЦЯТИПАЛОЇ КИШКИ

О.О.Герасимова, А.А.Красюк

Національний фармацевтичний університет

Ключові слова: виразкова хвороба шлунка; виразкова хвороба дванадцятипалої кишки; антихелікобактерна терапія; витрати на лікування

\begin{abstract}
Представлені результати оцінки витрат на схеми антихелікобактерної терапії виразкової хвороби шлунка та дванадиятипалої кишки, рекомендовані українським уніфікованим клінічним протоколом надання медичної допомоги дорослим пацієнтам з даним захворюванням (Наказ МОз України №613 від 03.09.2014 р.), який створено з урахуванням принципів доказової медицини. Встановлено, що більшість лікарських препаратів, які використовуються у складі схем антихелікобактерної терапії, була наявна на фармацевтичному ринку України у 2014 році в достатній кількості з широким діапазоном цін за упаковку. Діапазон вартості антихелікобактерної терапії складає: перша лінія терапії - від 87,50 до 3400,88 грн (трикомпонентна терапія - від 181,44 до 3400,88 грн; послідовна терапія - від 87,50 до 1837,65 грн); друга лінія терапії (квадротерапія) - від 202,60 до 2059,19 грн; терапія «порятунку» - від 157,08 до 3298,93 грн. Загальна вартість терапії хворого, якому допомогла тільки терапія «порятунку», складає від 628,62 до 10596,65 грн. Запропоновані варіанти схем антихелікобактерної терапії, сформовані з лікарських препаратів, представлених на українському фармацевтичному ринку, наявні в Державному формулярі лікарських засобів України і мають найменшу вартість на курс антихелікобактерної терапії захворювання. Їх використання є економічно доцільним для українських пацієнтів з виразковою хворобою шлунка та дванадиятипалої кишки з низькою платоспроможністю.
\end{abstract}

\section{ОЦЕНКА ЗАТРАТ НА АНТИХЕЛИКОБАКТЕРНУЮ ТЕРАПИЮ ЯЗВЕННОЙ БОЛЕЗНИ ЖЕЛУДКА И ДВЕНАДЦАТИПЕРСТНОЙ КИШКИ \\ о.А.Герасимова, А.А.Красюк}

Национальный фармацевтический университет

Ключевые слова: язвенная болезнь желудка; язвенная болезнь двенадцатиперстной кишки; антихеликобактерная терапия; затраты на лечение

Представлены результаты оценки затрат на схемы антихеликобактерной терапии язвенной болезни желудка и двенадцатиперстной кишки, рекомендованные украинским унифицированным клиническим протоколом предоставления медищинской помощи взрослым пациентам с данным заболеванием (Приказ Моз Украины 
№613 от 03.09.2014 г.), который создан с учетом принципов доказательной медицины. Установлено, что большинство лекарственных препаратов, которые используются в составе схем антихеликобактерной терапии, присутствовали на фармацевтическом рынке Украины в 2014 году в достаточном количестве с широким диапазоном цен за упаковку. Диапазон стоимости антихеликобактерной терапии составляет: первая линия терапии - от 87,50 до 3400,88 грн (трикомпонентная терапия - от 181,44 до 3400,88 грн; последовательная терапия - от 87,50 до 1837,65 грн); вторая линия терапии (квадротерапия) - от 202,60 до 2059,19 грн; терапия «спасения» - от 157,08 до 3298,93 грн. Общая стоимость терапии больного, которому помогла только терапия «спасения», составляет от 628,62 до 10596,65 грн. Предложены варианты схем антихеликобактерной терапии, сформированные из лекарственных препаратов, которые представлены на украинском фармацевтическом рынке, присутствуют в Государственном формуляре лекарственных средств Украины и имеют наименьшую стоимость на курс антихеликобактерной терапии заболевания. Их применение экономически целесообразно для украинских пациентов с язвенной болезнью желудка и двенадцатиперстной кишки с низкой платежеспособностью.

Address for correspondence:

Received in 11.04.2016

4, Valentynivska str., Kharkiv, 61168, Ukraine.

Tel. (572) 65-88-95. E-mail: ph-econom@nuph.edu.ua.

National University of Pharmacy 